Haya: The Saudi Journal of Life Sciences

Abbreviated Key Title: Haya Saudi J Life Sci ISSN 2415-623X (Print) |ISSN 2415-6221 (Online) Scholars Middle East Publishers, Dubai, United Arab Emirates Journal homepage: https://saudijournals.com/sjls

Original Research Article

\title{
Prevalence and Abundance of Ticks Infesting Cattle and Sheep in Poro Region (Côte d'Ivoire)
}

\author{
Nawolo Yéo ${ }^{1 *}$, Zahouli Faustin Zouh Bi $^{2}$, Biégo Guillaume Gragnon ${ }^{1}$, Yahaya Karamoko ${ }^{3}$ \\ ${ }^{1}$ Laboratoire Régional de Korhogo (LRK), Laboratoire National d'Appui au Développement Agricole (LANADA), BP 32 Korhogo, Côte d'Ivoire \\ ${ }^{2}$ Centre de Recherche en Ecologie, Université Nangui Abrogoua, 08 BP 109 Abidjan 08, Côte d'Ivoire \\ ${ }^{3}$ Unité de Formation et de Recherche des Sciences de la Nature, Université Nangui Abrogoua, 02 BP 801 Abidjan 02, Côte d'Ivoire
}

DOI: $10.36348 /$ sjls.2020.v05i05.003 $\quad$ | Received: 04.05.2020 | Accepted: 14.05.2020 | Published: 21.05 .2020

*Corresponding author: Nawolo Yéo

Email: yeonawolo81@gmail.com

\section{Abstract}

In order to determine ticks' prevalence and abundance on cattle and sheep in the Poro Region of Côte d'Ivoire, 809 ticks were collected from 120 cattle and 311 ticks from 120 sheep. Six species have been identified: Amblyomma variegatum, Rhipicephalus (Boophilus) microplus, Boophilus annulatus, Boophilus geigyi, Hyalomma truncatum and Rhipicephalus senegalensis. Cattle were more infested by these ticks excluding Rhipicephalus senegalensis, which had a higher prevalence in sheep (12.5\% in sheep versus $4.17 \%$ in cattle). The species Boophilus geigyi was most abundant in cattle of Dikodougou department (42.96\%), then in sheep of Sinématiali $(60 \%)$ and M'Bengué $(51.72 \%)$ departments. In addition, Rhipicephalus senegalensis was more abundant in sheep in Korhogo Department with a proportion of 51.39\%. These results suggest that tick control needs to be strengthened to improve the productivity of domestic ruminants in the Poro Region of Côte d'Ivoire.

Keywords: Ticks, prevalence, abundance, sheep, cattle, Poro Region, Côte d'Ivoire.

Copyright @ 2020: This is an open-access article distributed under the terms of the Creative Commons Attribution license which permits unrestricted use, distribution, and reproduction in any medium for non-commercial use (NonCommercial, or CC-BY-NC) provided the original author and source are credited.

\section{INTRODUCTION}

In the world, ticks are considered as the second most important diseases vectors after mosquitoes [1]. They are cosmopolitan, but are present mainly in the tropical and subtropical regions with the hot and humid climate suitable for metamorphosis [2, 3]. They can transmit zoonotic parasites that can cause a public health problem [4]. Tick-borne diseases are an important source of morbidity for domestic animals [5, 6]. Studies have shown the existence of many species of livestock ticks [7]. Strong mortalities bound to the ticks were indicated at cattle of exotic races and half-bloods in Nigeria [8], in Cameroon [9] and in Ghana [10, 11]. According to Achi et al., [12], the only exhaustive data on ticks in Côte d'Ivoire are those of the works of Aeschlimann [13] and Morel [14] dating from 1950 to 1970. The present study has for objective to determine prevalence and abundance of ticks on farmed cattle and sheep in the Poro Region of Côte d'Ivoire.

\section{MATERIAL AND METHODS Study Areas}

The North of Côte d'Ivoire is composed of more than $80 \%$ of savanna formations which are the woody savanna, the raised savanna, the shrubby savanna and the grassy savanna. The climate is Sudanian with a single rainy season lasting six and a half months (mid-April to October), with a peak from July to October; a dry season with maximum influence from November to the end of March (FAO, 2005). The cattle production systems encountered in northern Côte d'Ivoire are sedentary livestock $(43 \%)$ and transhumant livestock $(50 \%)$ [15]. The sedentary herds include, in order of decreasing importance, the Baoulé, Zébu, N'Dama, half-blood Zébu-Baoulé and other half-bloods. The transhumant herd is essentially composed of zébus $(63 \%)$ [12].

\section{Tick Collection}

Tick collection was done from November to December 2015 in four departments of Poro region: Sinématiali, Korhogo, Dikodougou and M'Bengué (Figure-1). In each department, the collect was done on 30 cattle and 30 sheep, overall on 120 cattle and 120 sheep in the study area. Height hundred and nine (809) and 311 ticks were collected respectively on cattle and sheep. Ticks were collected with a pair of tongs after a good contention of animals, preventing the hypostom from breaking. Seven anatomical regions were observed 
on animals during this harvest. They are the anal region and the tail, the mammary region or of the scrotum, the stomach, the armpit, the plate of baleen, the head and the legs. Each bottle was labeled with the following: farm where sample was collected (name of the District or the region), date of harvest, ordinal number of the animal.

\section{Tick Counting and Identification}

Tick identification has been performed at the Animals Biology and Cytology Laboratory of Nangui Abrogoua University in Abidjan. The content of each bottle was poured into a kneaded box, and then the parasites were separated and counted by the ornamentation of the body, by the sex and by the physiological stage.
The species identification was completed under binocular lens at 80-fold magnification and a digital microscope (optical microscope) was used at 100-fold magnification for taking photos. This identification has focused on the morpho-anatomical characteristics of certain body parts (rostrum, punctuation of the scutum, the tint (coloring) of legs, shape of stigmas, shape of furrows(grooves), shape of festoons, shape of plates (patches) and eyes). It was possible thanks to the key of Walker et al., [16].

The tick species identified were organized by animal species and by department.

\section{Data analyzing and statistical treatments}

Microsoft Office Excel 2007 program was used to calculate prevalence and abundance of each tick species. Formulas used:

\section{Ticks prevalence on animals}

The formulas used to calculate prevalence of each tick species:

$$
\text { Prevalence }(\%)=\frac{\text { Number of animals carrying a given tick species }}{\text { Total number of animals }} \times 100
$$

\section{Ticks abundance}

The formulas used to calculate abundance of each tick species:

$$
\text { Abundance }(\%)=\frac{\text { Total number of a given tick species }}{\text { Total number of ticks collected }} \times 100
$$

Statistical analyzes were performed within $\mathrm{R}$ Version 2.12.1 software. The statistical comparisons of those prevalence and abundances respectively by animal species and by department have been done respectively by $\mathrm{G}$ test. The different was significant when $\mathrm{p}$ value was lower than $0.05(\mathrm{p}<0.05)$.

\section{RESULTS AND DISCUSSION}

\section{Ticks collected on bovines and sheep}

A sample of 809 ticks was considered in Bovines. Concerning sheep, 311 ticks were collected (Table-1). All the tick species identified were present on the two animal species (bovines and sheep). Identification mainly based on morpho-anatomical characters has revealed the presence of six species of ticks from four genera Amblyomma, Rhipicephalus, Boophilus and Hyalomma. These species were Amblyomma variegatum, Rhipicephalus senegalensis, Boophilus microplus, Boophilus annulatus, Boophilus geigyi and Hyalomma truncatum (Photography 1 to 12).

These tick species had also found by Knopf $e t$ al., [17] on cattle in the north of Côte d'Ivoire and by Farougou et al., [6] on sheep in the meridional region of Benin. Their presence in cattle and sheep farms of Poro regions in northern Côte d'Ivoire could be explained by their adaptation to humidity and survey conditions in this area.

Furthermore, the presence of these tick species on cattle and sheep could be explained by mixed control of cattle and sheep in the breed sampled in this area. Indeed, cattle and sheep used the same pasture and yet the fight against ticks was not systematic at these two animal species. In addition, the absence of artificial pastures could favor the chronic infestation of animals.

\section{Prevalence of the different tick species identified}

In this study, the prevalence of $A$. variegatum, $B$. microplus, B. annulatus, B. geigyi and $H$. truncatum obtained on cattle were higher than ones of sheep, excluding that of $R$. senegalensis which was higher for sheep (12.5\% for sheep and $4.17 \%$ for cattle). Moreover, the prevalence of the species $B$. geigyi on cattle $(53.33 \%)$ was higher than ones of $A$. variegatum $(48.33 \%)$ and B. microplus (47.50\%). As far as concerning sheep, the prevalence of B. geigyi $(38.33 \%)$ was once again higher than the one obtained for $A$. variegatum (32.50\%), which also was higher than one of B. microplus (3.33\%) (Figure-2).

Among all the ticks collected in this study, the species B. geigyi was the most abundant one the two animal species. It represented $53.33 \%$ of ticks collected on cattle and $38.33 \%$ of ticks collected on sheep. This species was followed by $A$. variegatum which represented $48.33 \%$ of ticks collected on cattle and $32.50 \%$ of ticks collected on sheep. However, This was not in agreement with previous study undertaken by Achi et al., [12] on cattle reared in traditional farms in northern Côte d'Ivoire. According to these authors, the species A. variegatum was the most encountered (66 to $90 \%$ of ticks collected), followed by Boophilus spp (8 
to $33 \%$ of ticks collected). It was the same for Farougou et al., [18] and Hasen et al., [19]. Hence, the results of Farougou et al., [18] shown that A. variegatum was the most abundant tick (89.70\%) on sheep in Benin meridonial region. For Hasen et al., [19] in Ethiopia, $A$. variegatum was also the most present on farmed cattle $(83.72 \%)$. On the other hand, for Nateneal et al., [3], Kibruyesfa and Achuna [20], the proportion of this tick species was the lowest on cattle reared in Ethiopia. Indeed, these authors obtained respectively $6.5 \%$ and $3.9 \%$ of all ticks collected on cattle.

The abundance of the species B. geigyi in the study area could be explained by the fact that the climatic conditions of savanna which characterize the northern Côte d'Ivoire [16], are favor to this tick's development. In addition, $A$. variegatum was abundant because ticks were collected in its development period which is from October to February [16].

\section{Abundance of different tick species on cattle and sheep according to departments}

Ticks were more present on cattle in Dikodougou and Korhogo departments (Respectively $35.97 \%$ and $31.27 \%$ ) than departments of Sinématiali and M'Bengué (Respectively $16.44 \%$ and $16.32 \%$ ). On the other side, concerning sheep, ticks were most present only in the department of Korhogo (46.30\%) (Figure-3).

Among all the ticks collected on cattle, the species $B$. geigyi and $B$. microplus was the most abundant in Dikodougou department. They represented respectively $42.96 \%$ and $36.43 \%$ of ticks' total number in this department. In the department of M'Bengué, they were also the most abundant $(33.33 \%$ for $B$. microplus and $29.55 \%$ for $B$. geigyi). As far as concerning the species $A$. variegatum, it was the most abundant in korhogo and Sinématiali departments and represented respectively $48.22 \%$ and $34.59 \%$ of ticks collected on cattle.

The species $B$. annulatus was most encountered in the department of Sinématiali $(24.06 \%)$ whereas the proportions of the species $H$. truncatum and $R$. senegalensis were the lowest in all departments (Table-2).

Among all the ticks collected on sheep in Sinématiali and M'Bengué, the species B. geigyi was the most abundant. Its proportion was $60 \%$ in Sinématiali and $51.72 \%$ in M'Bengué. On the other side, the species $R$. senegalensis was the most present on sheep of Korhogo department with a proportion of $51.39 \%$. Concerning the Dikodougou department, $A$. variegatum was the most encountered $(35.59 \%)$ on sheep (Table-3).

This abundance of ticks on farm animals in these departments is due to a loosening of the detagging of animals during the harvest period. In addition, the use of the same natural pasture by cattle and sheep in these different localities could be the source of infestations observed in these two animal species.

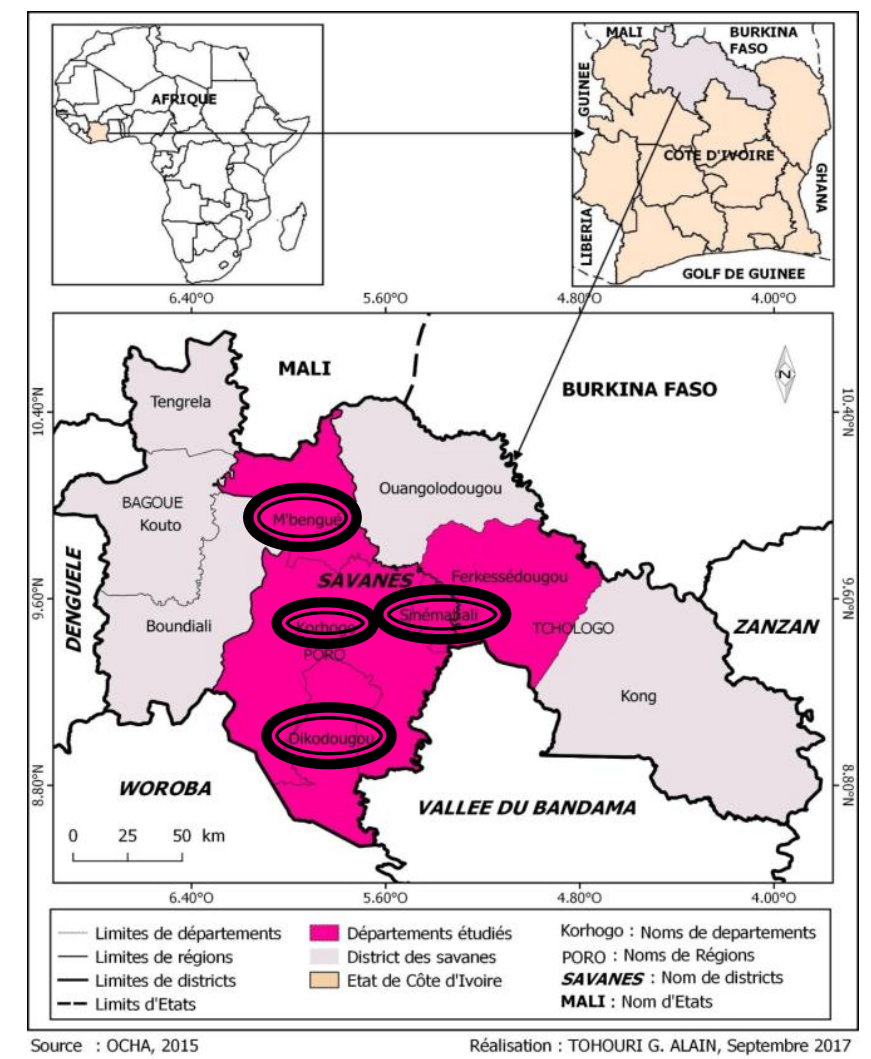




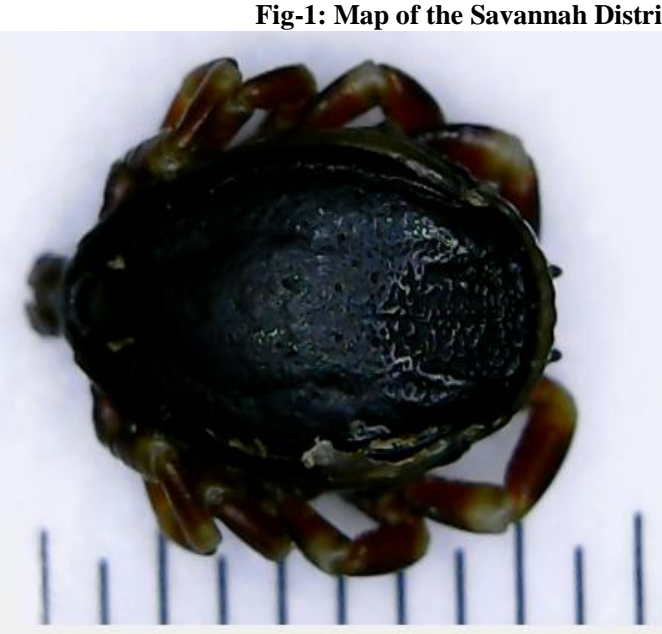

Photography 1: Hyalomma truncatum (Male, dorsal sight)

Echelle: $1 \mathrm{~cm}$ for $10 \mathrm{~mm}$

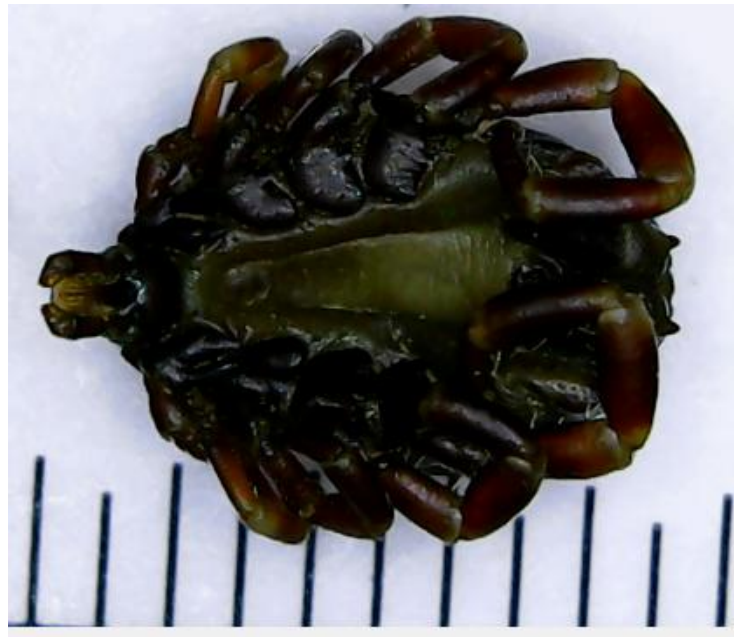

Photography 2: Hyalomma truncatum ((Male, ventral sight)

Echelle: $1 \mathrm{~cm}$ for $10 \mathrm{~mm}$

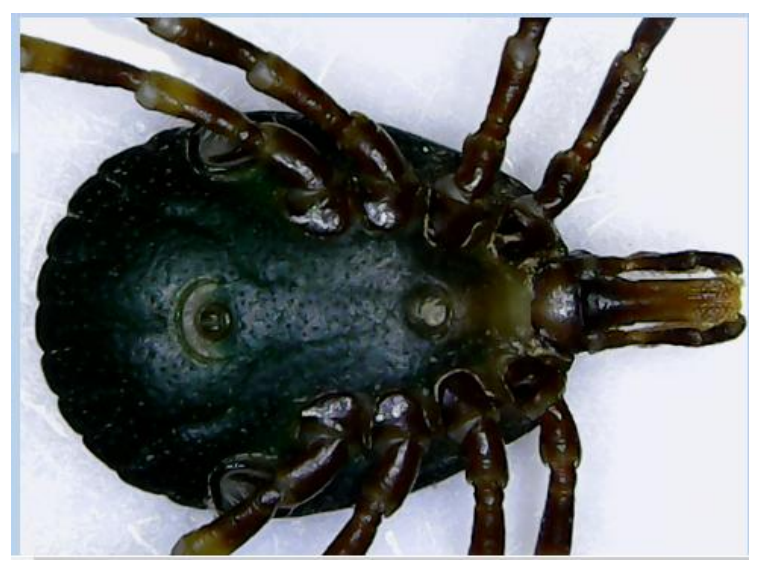

Photography 3: Amblyomma variegatum (Female, ventral sight)

Echelle: $1 \mathrm{~cm}$ for $10 \mathrm{~mm}$

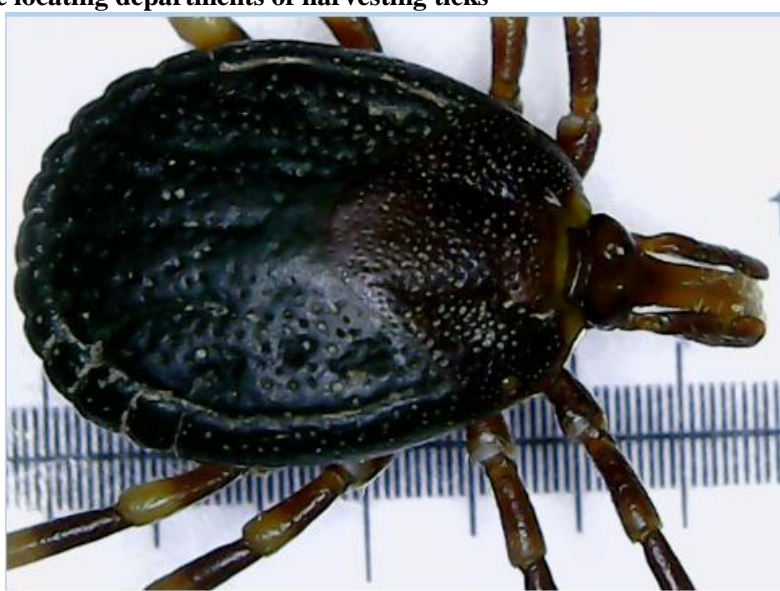

Photography 4: Amblyomma variegatum (Femelle, dorsal sight)

Echelle: $1 \mathrm{~cm}$ for $10 \mathrm{~mm}$

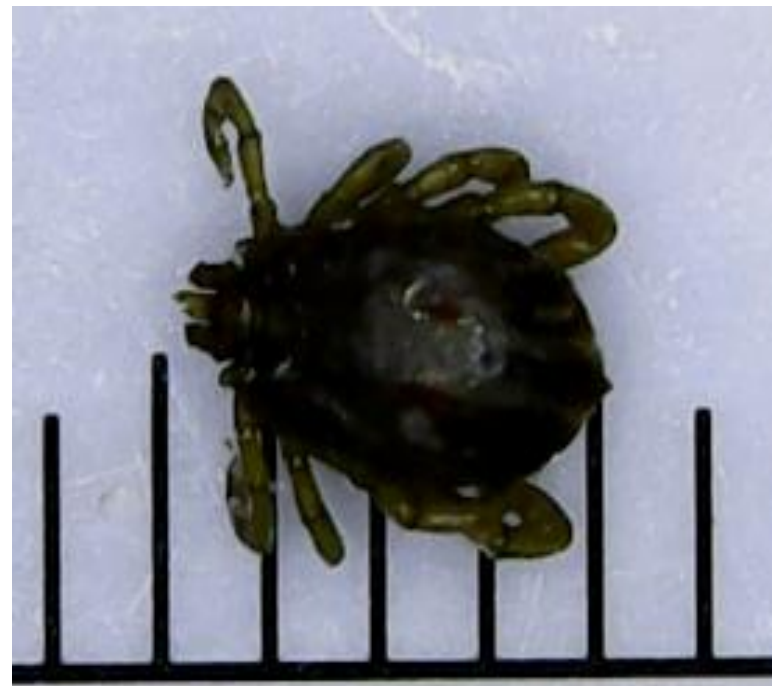

Photography 5: Rhipicephalus (Boophilus) microplus (Male, dorsal sight)

Echelle: $1 \mathrm{~cm}$ for $10 \mathrm{~mm}$

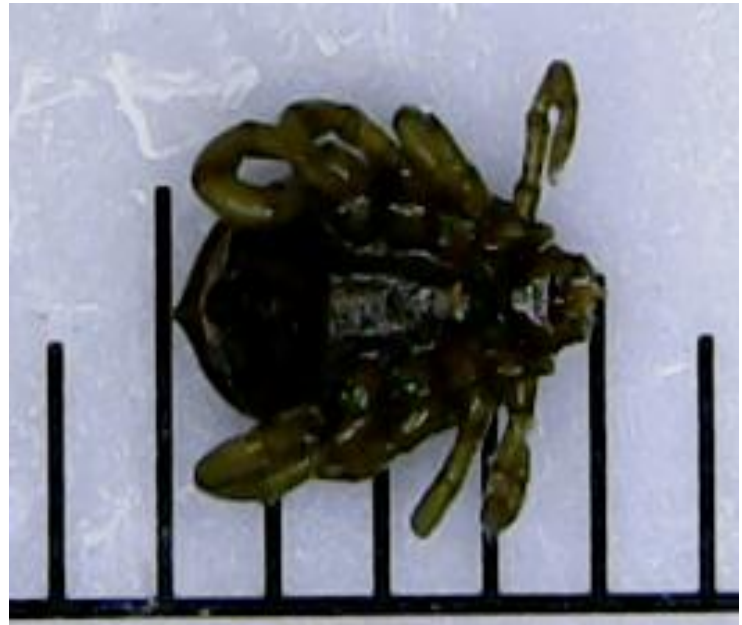

Photography 6: Rhipicephalus (Boophilus) microplus (Male, ventral sight)

Echelle: $1 \mathrm{~cm}$ for $10 \mathrm{~mm}$ 


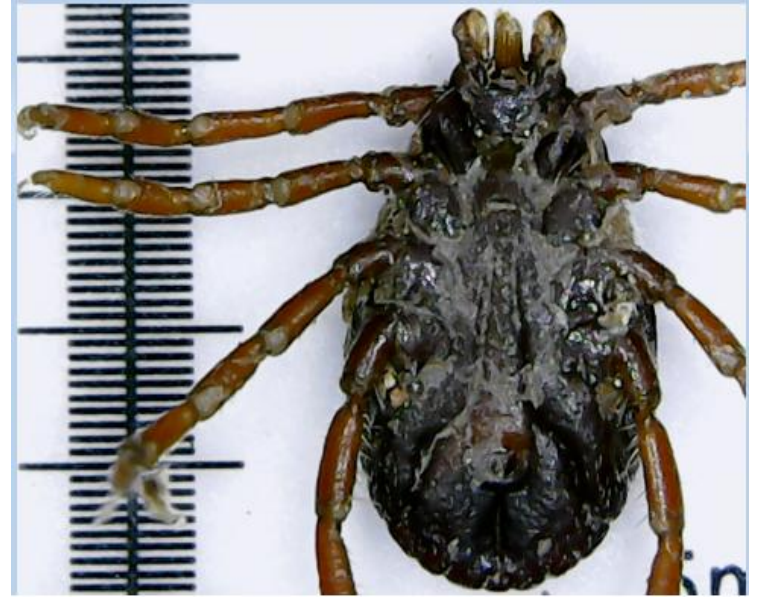

Photography 7: Rhipicephalus senegalensis (Male, ventral sight)

Echelle: $1 \mathrm{~cm}$ for $10 \mathrm{~mm}$

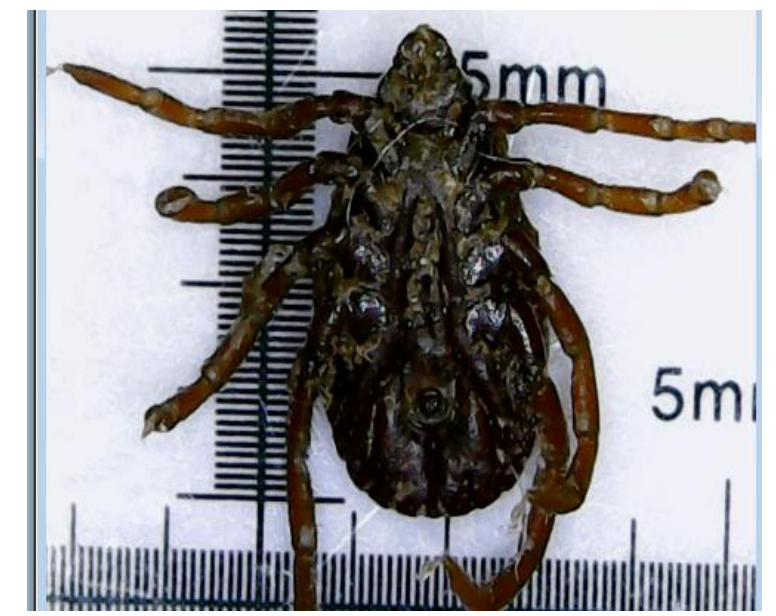

Photography 8: Rhipicephalus senegalensis (Femelle, ventral sight)

Echelle: $1 \mathrm{~cm}$ for $10 \mathrm{~mm}$

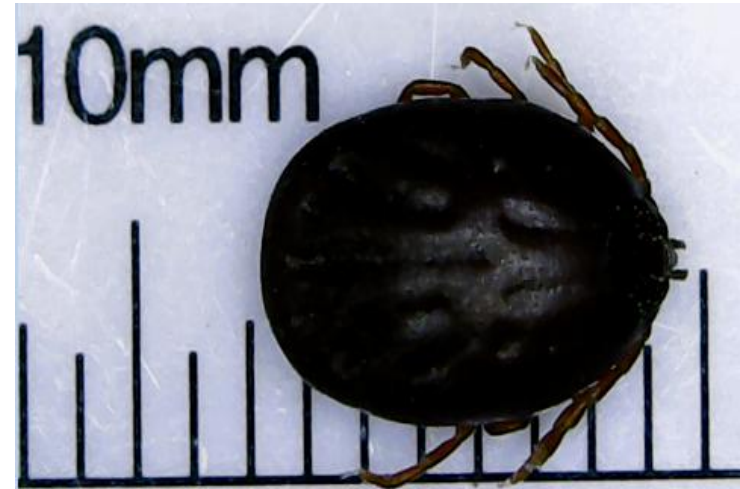

Photography 9: Boophilus geigyi (Femelle, dorsal sight)

Echelle: $1 \mathrm{~cm}$ for $10 \mathrm{~mm}$

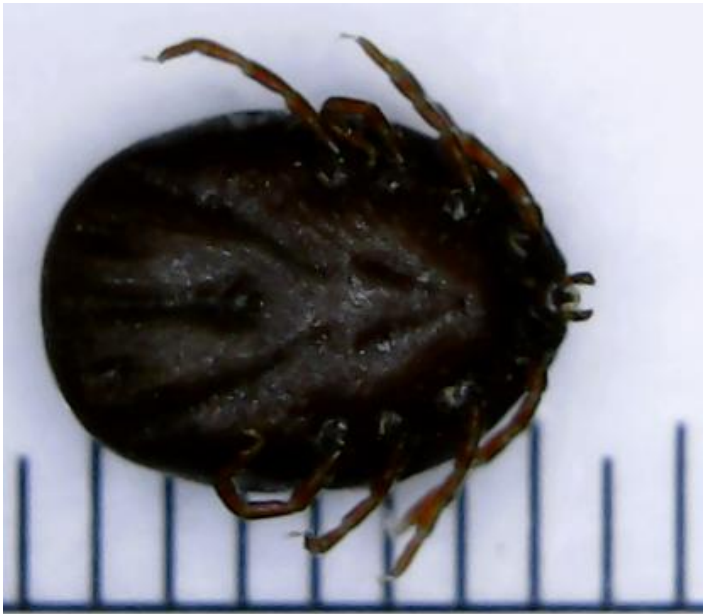

Photography 10: Boophilus geigyi (Femelle, ventrale sight)

Echelle: $1 \mathrm{~cm}$ for $10 \mathrm{~mm}$

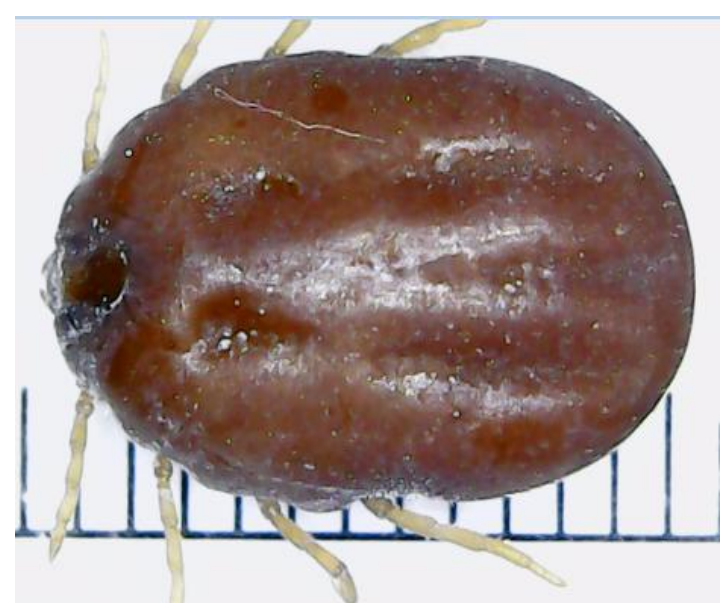

Photography 11: Boophilus annulatus (Femelle, dorsale sight)

Echelle: $1 \mathrm{~cm}$ for $10 \mathrm{~mm}$

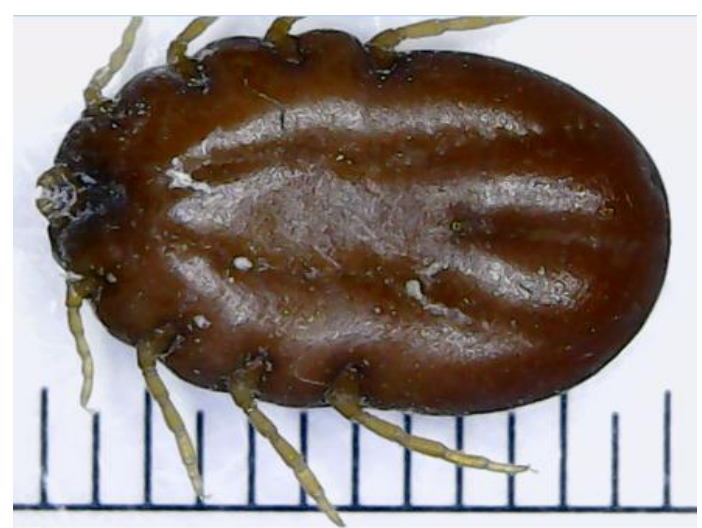

Photography 12: Boophilus annulatus (Femelle, ventral sight)

Echelle: $1 \mathrm{~cm}$ for $10 \mathrm{~mm}$ 


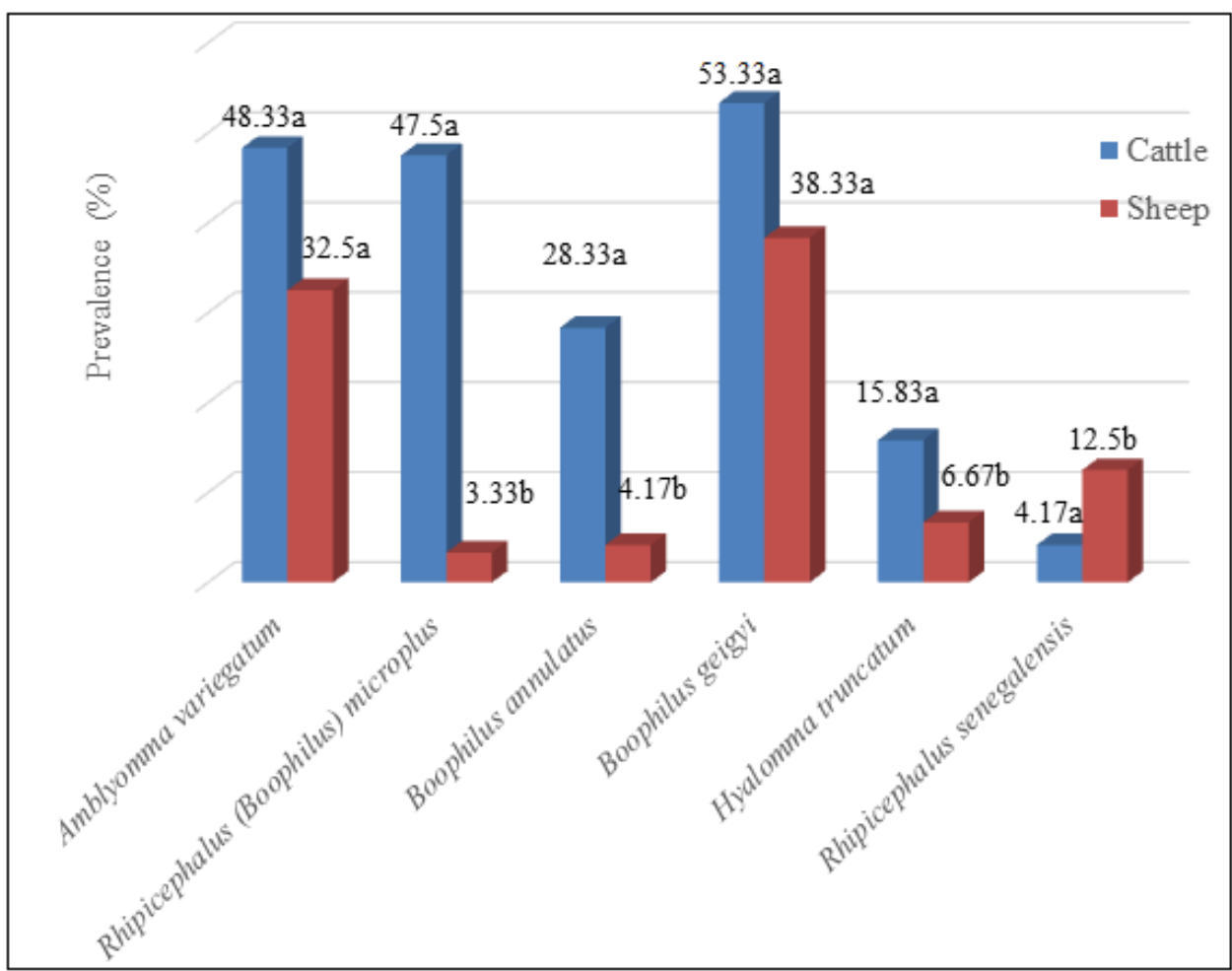

Fig-2: Comparison of prevalence of cattle and sheep tick species in the Poro Region

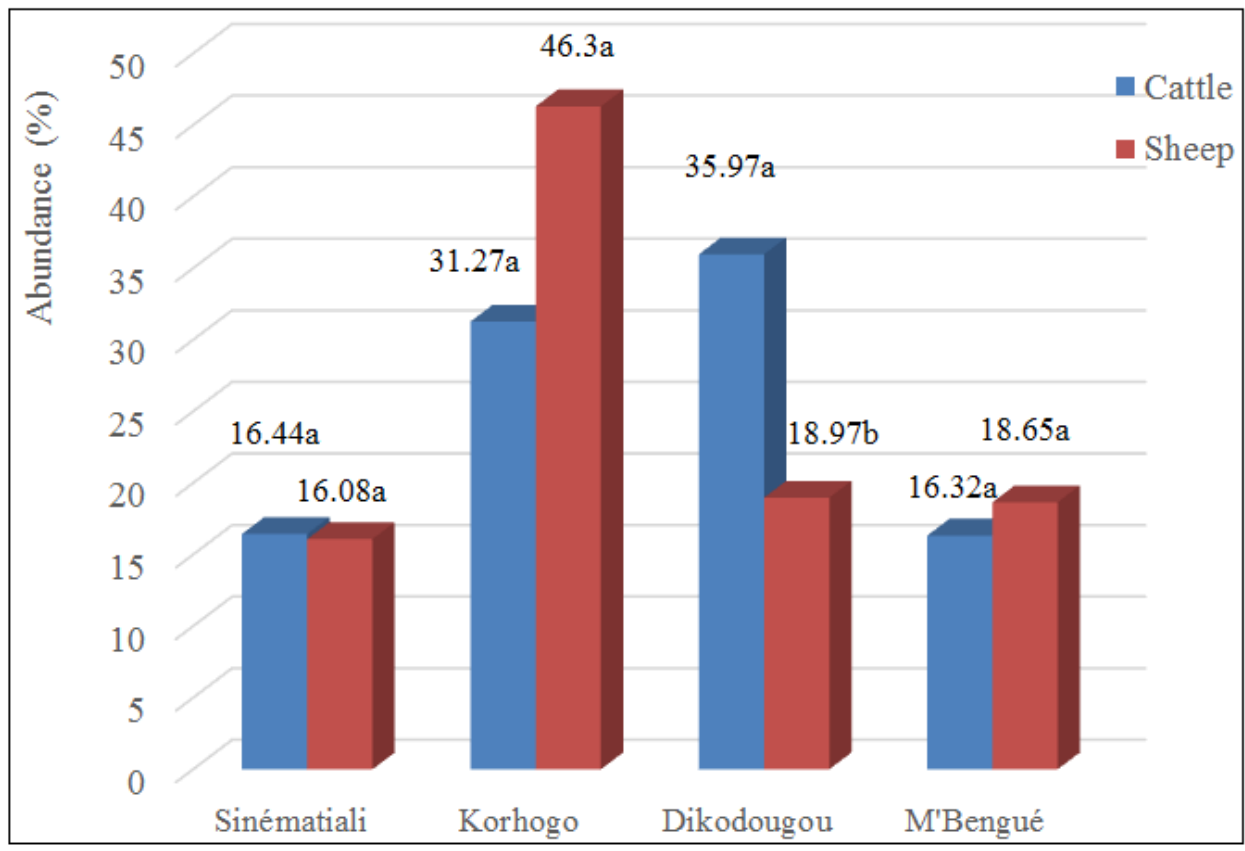

Fig-3: Comparison of tick abundances on cattle and sheep according to collection site

Table-1: Taxonomic structure of ticks collected from cattle and sheep in the Poro region

\begin{tabular}{|l|l|c|c|}
\hline \multicolumn{1}{|c|}{ Genres } & Tick species & Tick numbers on cattle & Tick numbers on sheep \\
\hline Amblyomma & Amblyomma variegatum & 208 & 75 \\
\hline Hyalomma & Hyalomma truncatum & 40 & 18 \\
\hline \multirow{3}{*}{ Boophilus } & Boophilus annulatus & 118 & 11 \\
\cline { 2 - 4 } & Boophilus geigyi & 233 & 98 \\
\hline \multirow{2}{*}{ Rhipicephalus } & Rhipicephalus (Boophilus) microplus & 195 & 33 \\
\cline { 2 - 4 } & Rhipicephalus senegalenis & 15 & 76 \\
\hline \multirow{2}{*}{ Total } & $\mathbf{8 0 9}$ & $\mathbf{3 1 1}$ \\
\hline
\end{tabular}


Table-2: Tick Species in Cattle by Department

\begin{tabular}{|l|c|c|l|c|c|}
\hline Tick species & \multicolumn{4}{|c|}{ Departments } & P>F \\
\hline & Sinématiali & Korhogo & Dikodougou & M'Bengué $^{\prime}$ & \\
\hline Amblyomma variegatum & $34.59^{\mathrm{a}}(46 / 133)$ & $48.22^{\mathrm{a}}(122 / 253)$ & $4.81^{\mathrm{b}}(14 / 291)$ & $19.7^{\mathrm{c}}(26 / 132)$ & $<0.0001^{*}$ \\
\hline R (Boophilus) microplus & $14.29^{\mathrm{a}}(19 / 133)$ & $10.28^{\mathrm{a}}(26 / 253)$ & $36.43^{\mathrm{b}}(106 / 291)$ & $33.33^{\mathrm{b}}(44 / 132)$ & $<0.0001^{*}$ \\
\hline Boophilus annulatus & $24.06(32 / 133)$ & $11.46(29 / 253)$ & $13.75(40 / 291)$ & $12.88(17 / 132)$ & 0.1180 \\
\hline Boophilus geigyi & $19.55^{\mathrm{a}}(26 / 133)$ & $17^{\mathrm{a}}(43 / 253)$ & $42.96^{\mathrm{b}}(125 / 291)$ & $29.55^{\mathrm{ab}}(39 / 132)$ & $<0.002^{*}$ \\
\hline Hyalomma truncatum & $7.52(10 / 133)$ & $7.51(19 / 253)$ & $2.06(6 / 291)$ & $3.79(5 / 132)$ & 0.1954 \\
\hline Rhipicephalus senegalensis & $0(0 / 133)$ & $5.53^{\mathrm{a}}(14 / 253)$ & $0(0 / 291)$ & $0.76^{\mathrm{b}}(1 / 132)$ & $<0.047^{*}$ \\
\hline
\end{tabular}

The values of the same line not bearing the same superscript letter differ significantly with the threshold from 0.05 for each parameter

$$
\text { * Significant }
$$

Table-3: Tick species in sheep by department

\begin{tabular}{|c|l|l|l|l|c|}
\hline Tick species & \multicolumn{4}{|c|}{ Departments } & P>F \\
\hline & Sinématiali & Korhogo & Dikodougou & M'Bengué $^{\prime}$ & \\
\hline Amblyomma variegatum & $8^{\mathrm{a}}(4 / 50)$ & $16.67^{\mathrm{a}}(24 / 144)$ & $35.59^{\mathrm{b}}(21 / 59)$ & $44.83^{\mathrm{b}}(26 / 58)$ & $<0.0001^{*}$ \\
\hline$R$ (Boophilus) microplus & $22^{\mathrm{a}}(11 / 50)$ & $2.08^{\mathrm{b}}(3 / 144)$ & $28.81^{\mathrm{a}}(17 / 59)$ & $3.45^{\mathrm{b}}(2 / 58)$ & $<0.0001^{*}$ \\
\hline Boophilus annulatus & $4(2 / 50)$ & $5.56(8 / 144)$ & $1.69(1 / 59)$ & $0(0 / 58)$ & 0.297 \\
\hline Boophilus geigyi & $60^{\mathrm{a}}(30 / 50)$ & $15.97^{\mathrm{b}}(23 / 144)$ & $25.42^{\mathrm{b}}(15 / 59)$ & $51.72^{\mathrm{a}}(30 / 58)$ & $0.0001^{*}$ \\
\hline Hyalomma truncatum & $2(1 / 50)$ & $8.33(12 / 144)$ & $8.47(5 / 59)$ & $0(0 / 58)$ & 0.059 \\
\hline Rhipicephalus senegalensis & $4^{\mathrm{a}}(2 / 50)$ & $51.39^{\mathrm{b}}(74 / 144)$ & $0(0 / 59)$ & $0(0 / 58)$ & $<0.0001^{*}$ \\
\hline
\end{tabular}

The values of the same line not bearing the same superscript letter differ significantly with the threshold from 0.05 for each parameter

$$
\text { * Significant }
$$

\section{CONCLUSION}

This study highlighted that farmed cattle and sheep of Poro region in Côte d'Ivoire carry six tick species. These species are: Amblyomma variegatum, $R$. (Boophilus) microplus, Boophilus annulatus, Boophilus geigyi, Hyalomma truncatum and Rhipicephalus senegalensis. Bovines were generally the most infested. The species Boophilus geigyi was the most abundant on cattle of Dikodougou department and one sheep of Sinématiali and M’Bengué departments.

The presence of these mites on cattle and sheep represents a major constraint to the development of domestic ruminant breeding in Côte d'Ivoire. Tick control measures through regular cattle and sheep removal in the same locality as well as a better pasture management are needed in order to reduce parasitic loads and to improve livestock production.

\section{ACKNOWLEDGEMENT}

The authors gratefully acknowledge the technical staff of Regional Laboratory of Korhogo (LRK) and the farmers who accepted to participate at this study.

\section{REFERENCES}

1. Parola, P., \& Didier, R. (2001). Ticks and tickborne bacterial diseases in humans: An emerging infectious threat. Clinical Infectious Diseases. 32, 897-928.
2. Kilpatrick, H., Howard, J., Andrew, M., \& Bonte, L. (2007). Managing Urban Deer in Connet cut: A Guide for Residents and Communities $2^{\text {nd }}$ edition. Connect cut Department of Environmental Protection, 6, 40.

3. Nateneal, T. B., Fikadu, E., Yimer, M., \& Jelalu, K. (2015). Identification and prevalence of ixodid tick in bovine at Bedele district, Oromiyia Regional State, Western Ethiopia. Journal Parasitol Vector Biol. 7(8), 156-162.

4. Zouh Bi, Z. F., Touré, A., Oka.Komoin, C., Karamoko, Y., \& Fantodji A. (2015). Prevalence of ticks infesting grasscutters (Thryonomys swinderianus Temminck, 1827) in the south of Côte d'Ivoire. Journal Appl Biosci. 87, 80858093.

5. Tatchell, R. J., Chimwani, D., Chirchir, S. J., Ong'are, J. O., Mwangi, E., \& Rinkanya, F., \& Whittington, D. (1986). Astudy of the justification for intensive tick control in Kenyan rangelands. Vet Rec, 119, 401-403.

6. Farougou, S., Kpodekon, M., Aakal, H., Sagbo, P., \& Boko, C. (2007). Abondance saisonnière des tiques (Acari: Ixodidae) parasites des ovins dans la région méridionale du Bénin. Revue Méd. Vét, 158(12):627-632.

7. Farougou, S., Kpodékon, M., Tchabodé, D. M., Youssao, A. K. I., \& Boko, C. (2006). Abondance saisonnière des tiques (Acari : Ixodidae) parasites des bovins dans la zone soudanienne du Bénin : 
cas des départements de l'Atacora et de la Donga. Ann Méd Vét, 150:145-152.

8. Leeflang, P. (1977). Tick-borne diseases of domestic animals in northern Nigeria. I. Historical review, 1923-1969. Trop Anim. Health Prod, 9(3): 147-52.

9. Stachurski, F., Musonge, E. N., Achu-kwi, M. D., \& Saliki J. T. (1993). Impact of natural infestation of Amblyommavariegatum on the liveweight gain of male Gudali cattle in Adamawa (Cameroon). Vet Parasitol, 49(2-4), 299-311.

10. Koney, E. B. M., Morrow, A. N., \& Heron, I. D. (1996). The association between Amblyomma variegatum and dermatophilosis: Epidemiology and immunology. Trop. Anim. Health Prod., 28, $18-25$.

11. Morrow, A. N., Koney, E. B. M., \& Heron, I. D. (1996). Control of Amblyomma variegatum and dermatophilosis on local and exotic breeds of cattle in Ghana. Trop Anim Hlth Prod, May 28(2 suppl), 44-86.

12. Achi, Y. L., Koné, P., Stachurski, F., Zinsstag, J., $\&$ Betschart, B. (2012). Impact des tiques sur des bovins métissés dans le Nord de la Côte d'Ivoire. Bull Anim Hlth Prod Afr, 60(2), 144.

13. Aeschlimann, A. (1967). Biologie et écologie des tiques (Ixodoidea) en Côte d'Ivoire. Acta Trop Separatum, 24, 282-405.

14. Morel, P. C. (1958). Les tiques des animaux domestiques de l'Afrique occidentale française. Rev Elev Méd Vét Pays trop. 30(1), 153-189.
15. FAO. (2005). L'irrigation en Afrique en chiffres Enquête AQUASTAT, 10.

16. Walker, A. R., Bouattour, A., Camicas, J. L., Estrada-Pena, A., Horak, I. G., Latif, A. A., Pegram, R. G., \& Preston, P. M. (2003). Ticks of domestic animals in Africa: a guide to identification of species. Biosciences report, Edinburgh, 221.

17. Knopf, L., Komoin-Oka, C., Betschart, B., Jongejan, F., Gottstein, B., \& Zinsstag, J. (2002). Seasonnal epidemiology of ticks and aspects of cowdriosis in N'Dama village cattle in the Central Guinea savannah of Côte d'Ivoire. Preventive Veterinary Medecine, 53, 21-30.

18. Farougou, S., Adakal, H., Biguezoton, A. S., \& Boko, C. (2012). Prévalence de l'infection d'Amblyommavariegatum par Ehrlichiaruminantium dans les élevages extensifs du Bénin. Revue de Médecine Vétérinaire, 163.

19. Hasen A. Y., Yemane T. M., Bekele Y., Abebe, M., \& Ejigu Z. (2017). Identification of Encountered Bovine Tick Species in and Around Gambela Town. American Journal of Entomology, 1(1): 1-5.

20. Kibruyesfa, B., \& Achuna, A. (2017). Prevalence and Identification of Ixodid Ticks on Cattle in Kimbibit District, North Shoa Zone, Ethiopia. Advances in Biological Research, 11(5) 271-277. 